\title{
Pharmacological Activity of some Nigeria Plants Extracts in the Remidiation of Alloxan-Induced Diabetes in Rats: A Review
}

\author{
Wilfred Chiahemen Agber* and Raphael Wanger Anyam \\ Department of Biological Sciences Benue State University Makurdi, Nigeria \\ acwilfredagber@gmail.com, brwanyam@yahoo.com
}

\begin{abstract}
Keywords: Alloxan, induced diabetes, Nigeria plants, medicinal, therapeutic, pharmacological
\end{abstract} activity, pathophysiology, normoglycemic, oral administration.

\begin{abstract}
Plants are considered to be medicinal if they possess pharmacological activities of possible therapeutic use. A narrative perspective of medicinal evidences on the biochemical effectiveness of plant extracts used in the treatment of diabetes in rats was reviewed. The review was designed to highlight the chemical constituents and pharmacological potentials of some Nigeria plants used in experimental diabetes. The literature survey reveals the therapeutic efficiency of crude aqueous extracts of many plant species used either independently or in combination with some standard drugs for the treatment of diabetes with rats. Identified literature show a considerable degree of overlap and consistency in methods and results of findings. Some plant extracts were reported to be more effective in combination with other plant extracts and also a few were more effective than many standard drugs. There is a good number of quality research regarding plant extracts for the treatment and management of diabetes in rats. These plants identified as having anti diabetic potentials may be remedy for the treatment and management of diabetes in human. Research should explode more about these valuable plants to ascertain the dosage that may be required for man and if possible develop novel drug molecules for the future.
\end{abstract}

\section{Introduction}

Diabetes is a complex and a multi-variate group of disorder that disturbs the metabolism of carbohydrates, fats and protein [1]. It is one of the most common diseases and constitutes the largest chronic disease burdens throughout the world [2]. The disease is characterized by complex pathophysiology, increased fasting and post prandial blood sugar levels as a result of the loss of glucose homeostasis and shortage or lack of insulin secretion [3,4]. There is a global concern about the rise in deaths from non communicable diseases like diabetes, in spite of the introduction of various hypoglycemic agents; diabetes and its complication continue to be a major problem in the world population [5]. Recently, the world diabetes prevalence was reported to be $8.5 \%$ [6] while it's cost in the United State alone was estimated to be \$245billion [7], in Africa, it consumes 7\% of the region healthcare budget and countrywide estimates show that over $1.4-4.6 \%$ Nigerians are diabetic[8].

Diabetes mellitus is classified into two major subtypes: Type I (Insulin-Dependent Diabetes Mellitus IDDM) and Type II (Non Insulin-Dependent Diabetes Mellitus NIDDM). The juvenileonset diabetes or IDDM results from a cellular mediated autoimmune destruction of $\beta$-cells of the pancreas and often appears mainly before 30 years old in individuals $[9,10]$. NIDDM or adult-onset diabetes results from the development of insulin deficiency and this condition usually appears after 40 years old but can occur early for obsess people [10,11].Patients suffering from type I are therefore totally dependent on exogenous sources of insulin while patients suffering from type II diabetes can be treated with dietary changes, exercise and medication. Type II diabetes is the most common form of diabetes constituting $90 \%$ of the diabetes population [12].

The management of diabetes today is largely guided by the work from the Diabetes Control and Complication Trial (DCCT) for type I diabetes and the United Kingdom Prospective Diabetes Study (UKPDS) for type II diabetes, but the management of this disease without any side effect is still a challenge to the medical community. Several drugs such as biguanides, sulfonylurea, 
thiozolidenediones etc are presently available to reduce hyperglycemia [12] but these drugs are restricted by their pharmacokinetic properties, secondary failure rate and accompanying side effects [13]. Thus, the search for a new or alternative class of compounds is essential to overcome diabetes problems. A suggested was earlier made from the ethno botanical information report that about 800 plants may possess anti-diabetic potentials [14]. In view of this, World Health Assembly adopted among its resolutions, the need for nationals of developing countries to be using locally available traditional medicinal plants for the treatment of diabetes [5].

Since time in memorial, several plants and plants derived compounds have been used in local health traditions in rural and tribal villages of Africa including Nigeria for the treatment of diabetes to control blood sugar levels of patients. Despite these, the medicinal efficacy of a greater number of plants is either known or unknown to the mainstream population. It has been reported by several researchers that, medicinal plants provide useful sources of new oral hypoglycemic compounds for the development of pharmaceutical entities or as dietary adjunct to the existing therapies $[15,16$, 17].

Investigations on hypoglycemic agents from medicinal plants following the recommendation made by World Health Assembly have become more important. An experimental evidence suggest the involvement of free radicals in the pathogenesis of diabetes and stated that, plants capable of neutralizing free radicals are effective in preventing diabetes and hence reducing the severity of diabetes complications [18].

Based on current research, medicinal plants will seemingly continue to play an important role as health aid. The increased dependency rate on this alternative form of treatment for diabetes became possible with emerging researches on a lot of plants with hypoglycemic properties using alloxan-induced diabetic rats and other animal models. Thus, the alloxan-induced diabetes mellitus serve as a pathological bio-model for testing a substance with supposed antioxidant activities in vivo (i.e. using a whole animal for the experiment).

This paper provides a narrative perspective of evidences on the biochemical effectiveness of some Nigeria plants extract used in the treatment of diabetes as studied in alloxan-induced diabetic rats. The review of the evidences sought to highlight and compare the treatment effect of crude aqueous extract of many plant species used either independently or in combination for the treatment of diabetes.

\section{Etymology, Structure and Properties of Alloxan}

Alloxan was first isolated by Brugnatelli in 1818 and was named in 1838 at the naming of 13 uric acid compounds by Justus Von Liebig and Friedrich Wöhler following the synthesis of urea in 1828. The name alloxan was derived from allantoin, a product of uric acid excreted by the fetus into the allantois, and oxaluric acid derived from oxalic acid and urea found in urine. Alloxan $(2,4,5,6-$ pyrimidinetetrone) is an oxygenated pyrimidine derivative which is solid in appearance but freely soluble as alloxan hydrate in aqueous solution. The compound has a density of $1.639 \mathrm{~g} / \mathrm{cm}^{3}$ and molar mass of $142.07 \mathrm{~g} / \mathrm{mol}$ with molecular formula $\mathrm{C}_{4} \mathrm{H}_{2} \mathrm{~N}_{2} \mathrm{O}_{4}$ [19].<smiles>O=C1NC(=O)C(=O)C(=O)N1</smiles>

Figure 1: Alloxan (2, 4, 5, 6-pyrimidinetetrone).

\section{Biological Effect/Mechanism of Action}

Alloxan is a toxic glucose analogue which selectively destroys insulin producing cells in the pancreas when administered to rodents and other animal species [19]. The selective killing of the insulin producing beta cells found in the pancreas causes an insulin dependent diabetics mellitus (Alloxan diabetes) with characteristics similar to type I diabetes in human [20]. The alloxan model 
of diabetes was first described in rabbits [21] where the selective uptake was found to be due to its structural similarity with glucose as well as the beta cells. Several studies have shown that alloxan is not toxic to the human beta cells even in very high doses, probably because of differing glucose uptake mechanism in humans and rodents $[20,22,23]$.

\section{Method of Data Collection/Information Acquisition}

The search approach taken for the review was dependent and included searching of electronic sources using selected terms from literature search strategy; the Google engine advanced search facility was used to identify relevant full primary research publications by Nigeria authors available online in well recognized journals. Grey literature were also retrieved; hand searching of journals was carried out to identify further relevant studies that investigated on the effect of plant extracts in alloxan-induced diabetic rats other than any other insulin antagonist and animal model. All titles and abstracts from relevant articles gotten from electronic sources were screened. Majority of the included studies evaluated or investigated on plant extract administered independently to alloxaninduced diabetic rats while a few were in combination with other plant extracts and with standard drugs. None of the included studies was conducted outside Nigeria.

Phytochemical Constituents and Pharmacological Activity.

The following data were extracted from included effective studies: plant studied, part of plant used, method of plant extract administration/duration, and active chemical compounds isolated from plant extract as well as mode of action of extract on experimental animals. This is presented in table one below.

Table 1: Some medicinal plants with significant anti diabetic activities in rats.

\begin{tabular}{|l|l|l|l|l|l|}
\hline Ref. & $\begin{array}{l}\text { Plant } \\
\text { studied }\end{array}$ & $\begin{array}{l}\text { Part of } \\
\text { plant } \\
\text { used }\end{array}$ & $\begin{array}{l}\text { Plant extract /active } \\
\text { chemical compounds } \\
\text { isolated }\end{array}$ & $\begin{array}{l}\text { Method employed } \\
\text { for extract } \\
\text { administration } \\
\text { and duration }\end{array}$ & $\begin{array}{l}\text { Action of extract } \\
\text { on experimental } \\
\text { animals }\end{array}$ \\
\hline 5 & $\begin{array}{l}\text { Mormodiaca } \\
\text { charantia }\end{array}$ & Leaves & $\begin{array}{l}\text { Methanolic extract and } \\
\text { alkaloids, flavonoid, } \\
\text { phenolic, steroids }\end{array}$ & $\begin{array}{l}\text { Oral administration } \\
\text { of extract for } 5 \\
\text { days following } \\
\text { alloxan induction }\end{array}$ & $\begin{array}{l}\text { Anti-oxidant } \\
\text { effect }\end{array}$ \\
\hline 24 & $\begin{array}{l}\text { Ocimum } \\
\text { gratissimum }\end{array}$ & Leaves & $\begin{array}{l}\text { Aqueous extract and } \\
\text { alkanoids flavonoid, } \\
\text { saponin, cardiac } \\
\text { glycosides }\end{array}$ & $\begin{array}{l}\text { Oral administration } \\
\text { of extract for 7 days } \\
\text { following alloxan } \\
\text { induction }\end{array}$ & $\begin{array}{l}\text { Anti } \\
\text { hyperglycemic } \\
\text { effect }\end{array}$ \\
\hline 25 & $\begin{array}{l}\text { Indigofera } \\
\text { pulchra }\end{array}$ & Leaves & $\begin{array}{l}\text { Hydromethanolic } \\
\text { extract and tannins, } \\
\text { saponins, flavonoids } \\
\text { and steroids }\end{array}$ & $\begin{array}{l}\text { Intraperitoneal } \\
\text { administration of } \\
\text { extract for one day } \\
\text { following alloxan } \\
\text { induction }\end{array}$ & $\begin{array}{l}\text { Hypoglycemic } \\
\text { and anti- } \\
\text { hyperglycemic } \\
\text { effect }\end{array}$ \\
\hline 26 & $\begin{array}{l}\text { Phyllanthus } \\
\text { amarus }\end{array}$ & $\begin{array}{l}\text { Whole } \\
\text { plant }\end{array}$ & $\begin{array}{l}\text { Aqueous crude extract } \\
\text { No active chemical } \\
\text { isolated }\end{array}$ & $\begin{array}{l}\text { Oral administration } \\
\text { of extract }\end{array}$ & $\begin{array}{l}\text { Hypoglycemic } \\
\text { effect }\end{array}$ \\
\hline 27 & $\begin{array}{l}\text { Phyllanthus } \\
\text { niruri }\end{array}$ & $\begin{array}{l}\text { Aerial } \\
\text { Parts of } \\
\text { whole } \\
\text { plant }\end{array}$ & $\begin{array}{l}\text { Methanol extract and } \\
\text { alkaloid, carbohydrate, } \\
\text { flavonoid, glycosides, } \\
\text { saponins, steroid, } \\
\text { tannins }\end{array}$ & $\begin{array}{l}\text { Oral administration } \\
\text { of extract for 28 } \\
\text { days }\end{array}$ & $\begin{array}{l}\text { Anti } \\
\text { hyperglycemic } \\
\text { effect }\end{array}$ \\
\hline
\end{tabular}




\begin{tabular}{|c|c|c|c|c|c|}
\hline 28 & $\begin{array}{l}\text { Hyphaene } \\
\text { thebaica }\end{array}$ & $\begin{array}{l}\text { Fruit } \\
\text { pulp } \\
\text { and } \\
\text { leaves }\end{array}$ & $\begin{array}{l}\text { Methanolic extract and } \\
\text { carbolydrates, } \\
\text { glycosides, flavonoids } \\
\text { saponins }\end{array}$ & $\begin{array}{l}\text { Oral administration } \\
\text { of extract for one } \\
\text { day following } \\
\text { alloxan induction }\end{array}$ & $\begin{array}{l}\text { Anti } \\
\text { hyperglycemic } \\
\text { effect }\end{array}$ \\
\hline 29 & $\begin{array}{l}\text { Icacina } \\
\text { trichantha }\end{array}$ & Tuber & $\begin{array}{l}\text { Methanol extract and } \\
\text { alkaloid, terpenes, } \\
\text { flovonoids, glycosides, } \\
\text { steroid, saponin, tannin }\end{array}$ & $\begin{array}{l}\text { Oral administration } \\
\text { for } 21 \text { days }\end{array}$ & $\begin{array}{l}\text { Anti } \\
\text { hyperglycemic } \\
\text { and anti lipidemic } \\
\text { effect }\end{array}$ \\
\hline 30 & \begin{tabular}{|l} 
Vernonia \\
amygdalina
\end{tabular} & Leaves & $\begin{array}{l}\text { Aqueous extract No } \\
\text { active chemical isolated }\end{array}$ & $\begin{array}{l}\text { Oral intubation for } \\
28 \text { days }\end{array}$ & $\begin{array}{l}\text { Hypoglycemic } \\
\text { effect }\end{array}$ \\
\hline 31 & $\begin{array}{l}\text { Mucuna } \\
\text { pruriens }\end{array}$ & Leaves & $\begin{array}{l}\text { Ethnolic extract and } \\
\text { Flavonoid, saponin, } \\
\text { tannins, cardiac } \\
\text { glycosides, triterpenes, } \\
\text { reducing sugars }\end{array}$ & $\begin{array}{l}\text { Oral administration } \\
\text { of extract for } 21 \\
\text { days following } \\
\text { alloxan induction }\end{array}$ & $\begin{array}{l}\text { Hypoglycemic } \\
\text { activity }\end{array}$ \\
\hline 32 & $\begin{array}{l}\text { Anacardium } \\
\text { occidentale\& } \\
\text { Gomphrena } \\
\text { globosa }\end{array}$ & Leaves & $\begin{array}{l}\text { Ethanolic extract and } \\
\text { alkaloids, flavonoid, } \\
\text { tannins, saponins }\end{array}$ & $\begin{array}{l}\text { Intraperitoneal } \\
\text { administration of } \\
\text { extract for } 3 \text { days } \\
\text { following alloxan } \\
\text { induction }\end{array}$ & $\begin{array}{l}\text { Hypoglycemic } \\
\text { effect }\end{array}$ \\
\hline 33 & $\begin{array}{l}\text { Cissus } \\
\text { cornifolia }\end{array}$ & Leaves & $\begin{array}{l}\text { Methanolic extract and } \\
\text { alkaloid, flavonoid, } \\
\text { saponin, steroid, } \\
\text { terpenoid, tannin }\end{array}$ & $\begin{array}{l}\text { Oral administration } \\
\text { for 13days }\end{array}$ & $\begin{array}{l}\text { Anti } \\
\text { hyperglycemic } \\
\text { effect }\end{array}$ \\
\hline 35 & $\begin{array}{l}\text { Jatropha } \\
\text { curcas }\end{array}$ & Roofs & $\begin{array}{l}\text { Aqueous extract and } \\
\text { flavonoids, tannins, } \\
\text { saponin, phlobatannin }\end{array}$ & $\begin{array}{l}\text { Oral administration } \\
\text { of extract for } \\
\text { 15days }\end{array}$ & $\begin{array}{l}\text { Anti } \\
\text { hyperglycemic } \\
\text { effect }\end{array}$ \\
\hline 36 & $\begin{array}{l}\text { Allium } \\
\text { sativum }\end{array}$ & Bulbs & $\begin{array}{l}\text { Aqueous extract of } \\
\text { garlic } \\
\text { No active chemical } \\
\text { isolated }\end{array}$ & $\begin{array}{l}\text { Direct stomach } \\
\text { intubation of extract } \\
\text { for } 21 \text { days } \\
\text { following alloxan } \\
\text { induction }\end{array}$ & $\begin{array}{l}\text { Preventive effect } \\
\text { on elevation of } \\
\text { blood glucose }\end{array}$ \\
\hline 37 & $\begin{array}{l}\text { Nauclea } \\
\text { latifolia }\end{array}$ & Leaves & $\begin{array}{l}\text { Ethanolic extract No } \\
\text { active chemical isolated }\end{array}$ & $\begin{array}{l}\text { Oral administration } \\
\text { of extract for } 14 \\
\text { days following } \\
\text { alloxan induction }\end{array}$ & $\begin{array}{l}\text { Hypoglycemic } \\
\text { effect }\end{array}$ \\
\hline 38 & $\begin{array}{l}\text { Naucle } \\
\text { alatifolia }\end{array}$ & Leaves & $\begin{array}{l}\text { Ethanol extract. No } \\
\text { active chemical } \\
\text { compound isolated }\end{array}$ & $\begin{array}{l}\text { Oral administration } \\
\text { of extract for } 14 \\
\text { days }\end{array}$ & $\begin{array}{l}\text { Anti infective } \\
\text { effect on pancreas }\end{array}$ \\
\hline 39 & $\begin{array}{l}\text { Moringaa } \\
\text { oleifera \& } \\
\text { Bridelia } \\
\text { ferruginea }\end{array}$ & Leaves & $\begin{array}{l}\text { Aqueous extract. No } \\
\text { active chemical isolated }\end{array}$ & $\begin{array}{l}\text { Oral administration } \\
\text { twice daily for } \\
\text { 7days }\end{array}$ & $\begin{array}{l}\text { Anti } \\
\text { hyperglycemic } \\
\text { effect }\end{array}$ \\
\hline 40 & $\begin{array}{l}\text { Moringaa } \\
\text { oleifera }\end{array}$ & Leaves & $\begin{array}{l}\text { Aqueous extract No } \\
\text { active chemical isolated }\end{array}$ & $\begin{array}{l}\text { Oral administration } \\
\text { for } 28 \text { days }\end{array}$ & $\begin{array}{l}\text { Preventive effect } \\
\text { on hyperglycemia }\end{array}$ \\
\hline 41 & $\begin{array}{l}\text { Moringa } \\
\text { oleifera }\end{array}$ & Leaves & $\begin{array}{l}\text { Aqueous extract and } \\
\text { proteins, fixed oils, fats, } \\
\text { carbohydrates }\end{array}$ & $\begin{array}{l}\text { Oral administration } \\
\text { for } 1 \text { day in } 6 \text { hours } \\
\text { of alloxan induction }\end{array}$ & $\begin{array}{l}\text { Hypoglycemic } \\
\text { effect }\end{array}$ \\
\hline
\end{tabular}


Indigenous names of reviewed plants

Table two below shows the indigenous names of plants reviewed in the present paper. The names are presented in five distinct languages.

Table 2: Vernacular names of some medicinal plants with significant anti diabetic activities in rats

\begin{tabular}{|c|c|c|c|c|c|c|}
\hline \multirow{2}{*}{$\begin{array}{l}\text { Botanical } \\
\text { Name }\end{array}$} & \multirow{2}{*}{$\begin{array}{l}\text { Common } \\
\text { Name }\end{array}$} & \multicolumn{5}{|c|}{ Vernacular Name } \\
\hline & & Hausa & Yoruba & Igbo & Tiv & Idoma \\
\hline $\begin{array}{l}\text { Hyphaen } \\
\text { ethebaica }\end{array}$ & Doum palm & Goriba & & Ubru & Kughul & \\
\hline $\begin{array}{l}\text { Phyllanthus } \\
\text { niruri }\end{array}$ & $\begin{array}{l}\text { Stone } \\
\text { breaker or } \\
\text { Seed-under- } \\
\text { leaf }\end{array}$ & & & Enyikonwa & & \\
\hline $\begin{array}{l}\text { Anacardium } \\
\text { ocidentale }\end{array}$ & Cashew & Kanju/Jambe & & & Shase & $\begin{array}{l}\text { Obonu } \\
\text { oyibo }\end{array}$ \\
\hline $\begin{array}{l}\text { Gomphrena } \\
\text { globosa }\end{array}$ & $\begin{array}{l}\text { Globe } \\
\text { amaranth or } \\
\text { Bachelor } \\
\text { button }\end{array}$ & & & & & \\
\hline $\begin{array}{l}\text { Ocimum } \\
\text { gratissimum }\end{array}$ & $\begin{array}{l}\text { Clove basil } \\
\text { or African } \\
\text { basil or } \\
\text { Sweet basil }\end{array}$ & $\begin{array}{l}\text { Daidoyo ta } \\
\text { gida }\end{array}$ & Efinrin & Nchuawu & $\begin{array}{l}\text { Kungureku } \\
\text { u tamen }\end{array}$ & Anyeba \\
\hline $\begin{array}{l}\text { Mucuna } \\
\text { pruriens }\end{array}$ & $\begin{array}{l}\text { Velvet bean } \\
\text { or Cowitch } \\
\text { or Devil bean }\end{array}$ & Karara & Yerepe & Agbara & Imyo & Anamajaja \\
\hline $\begin{array}{l}\text { Moringa } \\
\text { oleifera }\end{array}$ & $\begin{array}{l}\text { Drumstick } \\
\text { tree }\end{array}$ & Zogale & $\begin{array}{l}\text { Ewe- } \\
\text { Igbale }\end{array}$ & & Jegerede & Igerigedu \\
\hline $\begin{array}{l}\text { Nauclea } \\
\text { latifolia }\end{array}$ & $\begin{array}{l}\text { African } \\
\text { peach or } \\
\text { Pincushion } \\
\text { tree }\end{array}$ & $\begin{array}{l}\text { Tafashiya/ } \\
\text { Igiya }\end{array}$ & Egbesi & Ubuluinu & $\begin{array}{l}\text { Ikura i } \\
\text { ukase }\end{array}$ & \\
\hline $\begin{array}{l}\text { Allium } \\
\text { sativum }\end{array}$ & Garlic & Taparnuwa & & & $\begin{array}{l}\text { Alabesa } \\
\text { upupuu }\end{array}$ & \\
\hline $\begin{array}{l}\text { Mormodaica } \\
\text { charantia }\end{array}$ & $\begin{array}{l}\text { Bitter melon } \\
\text { or Bitter } \\
\text { gourd or } \\
\text { Balsam pear }\end{array}$ & Garafuni & $\begin{array}{l}\text { Ejirin- } \\
\text { were }\end{array}$ & & & \\
\hline $\begin{array}{l}\text { Vernonia } \\
\text { amygdalina }\end{array}$ & Bitter leaf & Shuwaka & Ewuro & Olugbu & Ityuna & $\begin{array}{l}\text { Afolo, Ebo, } \\
\text { Atila, Ilo } \\
\text { Ichiwaka, }\end{array}$ \\
\hline $\begin{array}{l}\text { Phyllanthus } \\
\text { amarus }\end{array}$ & & Gerontsuntsaye & & & & \\
\hline $\begin{array}{l}\text { Bridelia } \\
\text { ferruginea }\end{array}$ & & Kizni, Kirni & Asaragba & Ola, Aga & Kpine & Ede \\
\hline $\begin{array}{l}\text { Cissus } \\
\text { cornifolia }\end{array}$ & $\begin{array}{l}\text { Black wild } \\
\text { grape } \\
\text { Ivy grape }\end{array}$ & $\begin{array}{l}\text { Rigarbirii } \\
\text { (robe of the } \\
\text { monkey) }\end{array}$ & & & & \\
\hline $\begin{array}{l}\text { Jatropha } \\
\text { curcas }\end{array}$ & $\begin{array}{l}\text { Barbados nut } \\
\text { or Physic nut }\end{array}$ & Bi ni da zugu & $\begin{array}{l}\text { Lapalapa } \\
\text { funfun }\end{array}$ & & Gyedan & $\begin{array}{l}\text { Ochigbede, } \\
\text { Ugbobruma }\end{array}$ \\
\hline $\begin{array}{l}\text { Icacina } \\
\text { trichantha }\end{array}$ & & & Gbegbe & Ibugo & & \\
\hline
\end{tabular}




\section{Literature Review}

Traditional healers/folk medicine practitioners claimed that Ocimum gratissimum cures diabetes, this prompted [24] to study the anti diabetic activity of aqueous leaves extract of $O$. gratissimum in alloxan induced diabetic rats. The authors observed that Oral administration of the extract daily for 7 days at doses of $50,100,200$ and $400 \mathrm{mg} / \mathrm{kg}$ produced a significant $(\mathrm{p}<.05)$ reduction in plasma glucose level in the diabetic rats. They found a highest reduction in plasma glucose from $10.0 \pm 3.6 \mathrm{mmol} / \mathrm{L}$ in the diabetic group to $1.8 \pm 0.06 \mathrm{mmol} / \mathrm{L}$ in the group administered $100 \mathrm{mg} / \mathrm{kg}$ of the aqueous extract. The result of the study suggests the validity of the clinical use of Ocimum gratissimum in the treatment of diabetes mellitus.

The hydromethanolic effect of leaves extract of Indigofera pulchra on blood glucose levels of alloxan induced and normoglylcemic Wister rats was also investigated [25]. The blood glucose of all diabetic rats was significantly $(\mathrm{p}<.05)$ decreased at the $24^{\text {th }}$ hour only' following the administration of 250,500 and $1000 \mathrm{mg} / \mathrm{kg}$ doses of methanol extract. The researchers reported a median lethal dose of $2154 \mathrm{mg} / \mathrm{kg}$ body weight of extract. Extract from the leaves of Indigofera pulchra was confirmed to possess hypoglycemic effect. Similarly, another study reported the anti diabetic activities of leaf extract of Phyllanthus amarus in alloxan-induced diabetic Wister albino rats [26]. They observed a significant $(\mathrm{p}<0.05)$ reduction in blood glucose level at $24^{\text {th }}$ hour following an administration of a $260 \mathrm{mg} / \mathrm{kg}$ dose of extract to the diabetic rats. When dose level was increased to $390 \mathrm{mg} / \mathrm{kg}$, a more significant $(\mathrm{p}<0.001)$ reduction in blood glucose level was further observed on the 7 and 14 day of the study. However, mortality was observed at a dose of $1500 \mathrm{mg} / \mathrm{kg}$ and above on acute toxicity studies. The result of the study indicates the presence of hypoglycemic constituent in the plant.

The methanol extract of aerial parts of Phyllanthus niruri were administered to alloxan induced diabetic albino rats, fasting blood glucose of all albino rats was reduced $(p<0.05)$ in a dose related manner and the post prandial rise in blood glucose after a heavy glucose meal was also found to be suppressed. Total cholesterol and triglyceride were observed to be significantly reduced in diabetic and normoglycemic rats following a chronic oral administration of methanol extract of $P$. niruri. An increase in weight of methanol extract treated rats was observed throughout their study. The researchers results also showed that diabetic rats treated with methanol extract had the tissue organization of their pancreas restored. Acute toxicity testing of the methanol extract gave an oral lethal dose $\left(\mathrm{LD}_{50}\right)$ of $471 \mathrm{mg} / \mathrm{kg}$. The results suggest that methanol extract of aerial parts of $P$. niruri has great potentials as anti diabetic remedy [27].

Extract of parts of various plants claimed to possess anti diabetic properties such as Hyphaene thebaica, Boscia senegalensis, Bolanitea egyptica and Anisopus manii were studied in normal and alloxan induced diabetic white Wister strain albino rats. All plants were observed to possess anti diabetic potentials but the highest effect of $28.4 \%$ was seen with Hyphaene thebaica at a dose level of $400 \mathrm{mg} / \mathrm{kg}$ body weight. The study further centered on H.thebaica fruit pulp. Methanol extract from the fruit pulp had maximum reduction of $33.1 \%$ in blood glucose for normoglycemic rats and $33.7 \%$ for diabetic rats at the same dose of $800 \mathrm{mg} / \mathrm{kg}$. The researchers found that the effect of the methanol extract was better than the maximum reduction observed in diabetic rats administered with standard glibenclamid drug [28].

The anti diabetic, hypolipidemic activity and histopathological changes of Icacina trichantha tuber extract was investigated in alloxan induced diabetic Wister albino rats. Daily oral administration of tuber extract of I. trichantha $(200,400$ and $600 \mathrm{mg} / \mathrm{kg}$ body weight) and glibenclamid $(2 \mathrm{mg} / \mathrm{kg})$ produced a significant $(\mathrm{p}<0.01)$ blood glucose reduction as well as improving the kidney function, liver function and hyperlipidemia levels. Treated rats appeared normal and did not display any significant changes in behavior or neurological responses up to the dose of $1500 \mathrm{mg} / \mathrm{kg}$ revealing a non-toxic nature of $I$. trichantha. The study showed a dose dependent reduction in blood glucose and a favorable effect on the histopathology changes of the pancreas in alloxan induced diabetic rats. Study validates the traditional use of I. trichantha tuber for the management of diabetes [29]. 
A combination of extract from the leaves of Vernonia amygdalina with oral hypoglycemic agents as studied in alloxan induced diabetic albino rats. $V$. amygdalina was observed to be efficient in blood sugar lowering activity. The combination of a standard drug/extract revealed a more significant effect than as separate solutions. The reduction in weight of the experimental animals after induction of alloxan was found to be significantly restored with time on treatment with the aqueous extract. Their investigation demonstrated that the use of a combination of the extract from leaves of $V$. amygdalina and metformin is safe, effective, cheap and more comfortable for the management of diabetes mellitus [30].

Evaluation of the anti-diabetic activity of ethanolic leaf extract of Mucuna pruriens on blood glucose levels and histopathology of the pancreas reveals a significant reduction $(p<0.05)$ in the fasting blood sugar levels of alloxan-induced diabetic rats treated with 100,200 and $400 \mathrm{mg} / \mathrm{kg}$ of extract orally for twenty one days following alloxan induction. A lethal dose $\left(\mathrm{LD}_{50}\right)$ of $2154 \mathrm{mg} / \mathrm{kg}$ was observed in toxicity studies. Degenerated pancreatic Islet cells of diabetic animals were restored when treated with various doses of the plant extract during histopathology studies. The implication of the results obtained in the study provides the scientific rationale for the use of Mucuna pruriens as anti diabetic agent [31].

The hypoglycemic effect of enthanolic extract of Gomphrena globosa and Anacardium occidentale were evaluated in alloxan-induced diabetic Wister albino rats. Phytochemical screening reveals the presence of tannins, saponins, flavonoids and alkaloids. Intraperitoneal administration of 100 and $200 \mathrm{mg} / \mathrm{kg}$ body weight of extract concentration to animals models showed a significant $(\mathrm{p}<0.05)$ dose dependent reduction of blood glucose level in fasted alloxan induced diabetic rats. A lethal dose of $125 \mathrm{mg} / \mathrm{kg}$ body weight for $A$. occidentale was recorded while no death was recorded for all the concentrations used for G. globosa. This demonstrated that $A$. occidentale leaves extract was not safe at concentration over $125 \mathrm{mg} / \mathrm{kg}$ body weight. The researchers observed the hypoglycemic activities of the two plants to be dose dependent, they found the enthanolic leaves extract of G. globosa and A. occidentale possessed hypoglycemic properties [32].

An assessment of the effect of methanolic leaf extract of Cissus cornifolia on glucose concentration and histopathology of the pancreas and liver in alloxan induced hyperglycemic revealed a significant decrease $(p<.05)$ in blood glucose level at a dose of $100 \mathrm{mg} / \mathrm{kg}$ on the $7^{\text {th }}$ day of treatment with the highest activity of the aqueous extract residing at the lowest dose of $50 \mathrm{mg} / \mathrm{kg}$ body weight administered to the diabetic rats. Lethal dose $\left(\mathrm{LD}_{50}\right)$ was found to be above $5000 \mathrm{mg} / \mathrm{kg}$. When they sacrificed the diabetic animals, sectioning of the pancreas and liver for histopathology studies reveal the degeneration of pancreatic Islet cells but was restored after treatment with various doses of the plant extract. Cissus cornifolia was said to possess anti-diabetic potentials and was recommended by the authors to be used for the management of diabetes [33].

Effect of aqueous Mormodaica charantia extract on alloxan induced diabetic rats was determined. The researchers observed a significant $(p<0.05)$ decrease in blood glucose and a proportionate increase in body weight of all diabetic rats given the extract. The study showed that Mormodiaca charantia has significant effect on diabetes mellitus ${ }^{[5]}$. Similarly, another study investigated the effect of the methanolic extract of Mormodiaca charantia leaves on alloxan induced diabetic rats infected with malaria. Blood glucose of all treated groups of rats decreased significantly $(p<0.05)$ at the end of the experiment. They reported a decrease in parasitemia and a concomitant increase in parked cell volume and red blood cell count. Photomicrograph of the section of the pancreas and kidney of infected group of rats treated with $100 \mathrm{mg} / \mathrm{kg}$ of the plant extract showed mild degeneration of the Islet of Langerhan and mild atrophy of the glumeruli [34].

The effects of aqueous root extract of Jatropha curcas on some haematological parameters and its hypoglycemic potentials were investigated in alloxan-induced diabetic rats. The researchers observed a significant reduction in fasting blood glucose level $(\mathrm{p}<0.05)$ following an administration of $250 \mathrm{mg} / \mathrm{kg}$ and $400 \mathrm{mg} / \mathrm{kg}$ body weight of extract to diabetic rats once a day for 15 days. The study showed that aqueous extract of Jatropha curcas possess hypoglycemic activity and also improved the aberration in the blood parameter of alloxan-induced diabetic rats [35]. In another study, the preventive effect of Allium sativum was evaluated in alloxan induced diabetic rats. The researchers 
observed that pre-administration of garlic extract before alloxan induction prevents the elevation of blood glucose in alloxan induced diabetic rats. They observed this when garlic extract was administered to the rats seven days before alloxan induction and 14 days after induction. The implication of the experiment was that garlic eaten with other food supplements or eaten before a heavy meal of glucose can prevent the accumulation of glucose in the blood [36].

The hypoglycemic effect of ethanol extract and other fractions of Nauclea latifolia leaves were studied in normal and alloxan induced diabetic rats. The researchers observed a significant reduction $(p<0.05)$ in glycemic levels of diabetic rats with a maxima of $26.4 \%$ within 4 hours of treatment at a dose of $250 \mathrm{mg} / \mathrm{kg}$ of all extract fractions, this proved efficacious than the standard drug glibenclamid. Exploring the effect of ethanol extract and fractions of Nauclea latifolia leaves on the hematologic property of alloxan-induced diabetic Wister rats, some fractions of the extract showed capabilities to boost the immune system following an oral administered dose of $250 \mathrm{mg} / \mathrm{kg}$ once daily for 2 weeks to diabetic rats. This further proved to have anti infective property [37, 38].

Liver enzymes and anti diabetic activities of aqueous extract of Moringa oleifera and Bridelia ferruginea leaves were evaluated in alloxan induced diabetic albino rats. Both plants were found to show a significant reduction in plasma glucose level at an oral extract dose of 200, 400 and $800 \mathrm{mg} / \mathrm{kg}$ body weight of diabetic rats treated twice daily for seven days. The outcome of study suggests that both extracts can be used in ethno-medicine for the management of diabetes mellitus [39]. In another study, the effect of aqueous leaf extract of Moringa oleifera on plasma glucose level, total cholesterol, triglyceride, high density lipoprotein and low-density lipoprotein in male albino rats revealed that aqueous extract of Moringa oleifera reduces the plasma lipid imbalance associated with diabetes mellitus. This was observed when $400 \mathrm{mg} / \mathrm{kg}$ body weight of aqueous leaf extract was administered to male albino rats of the Wister strain for 28 days. Acute oral toxicity studies of $M$. oleifera extract did not show any mortality and toxic effect up to the dose of $2000 \mathrm{mg} / \mathrm{kg}$ body weight [40]. Similarly, another study found the blood sugar lowering effect of Moringa oleifera to be dose dependent. The researchers observed a percentage reduction in blood sugar level of $31.22 \%, 40.69 \%$ and $44.96 \%$ for 100,200 and $300 \mathrm{mg} / \mathrm{kg}$ dose of the extract respectively in 6 hours of administration which was as effective as the standard drug tolbutamid (46.75\%). Moringa oleifera was comparable with the reference drug tolbutamid [41]. The result of the 3 different studies provides a scientific rationale that Moringa oleifera can be used in the management and treatment of diabetes mellitus.

\section{Conclusion and Recommendation}

This review of qualitative research on the biochemical effectiveness of plants extract studied in alloxan-induced diabetic rats identified a number of strong themes in the literature reviewed, with a considerable degree of overlap and consistency in method and results of the findings. There is a good number of quality research regarding plant extracts for the treatment and management of diabetes in rats. Some plant extracts were reported to be more effective in combination with other plant extracts and also a few were more effective than many standard drugs. These plants identified as having anti diabetic potentials may be remedy for the treatment and management of diabetes in man. Research should explode more about these valuable plants to ascertain the dosage that may be required for man and if possible develop novel drug molecules for the future.

\section{References}

[1] C.R. Kahn, Y. Shechter. Insulin oral hypoglycemic agents and pharmacology of the endocrine pancreas in: A.G. Gilman, T.W. Rail, A.S. Nies and Taylor. The pharmacological basis of Therapeutics. Pergamon Press, New York, 1991, 1463-1495.

[2] D.B. Sacks et al., Guidelines and recommendations for laboratory analysis in the diagnosis and management of diabetes mellitus, Clin. Chem. 48 (2002) 436-472.

[3] S. Wild et al., Global prevalence of diabetes: Estimates for the year 2000 and projection for 2030. Diabetes Care. 5 (2004) 1047-1053. 
[4] S.K. Prasad, A. Kulshreshtha, N.Q. Taj, Anti diabetic activity of some herbal plants in STZinduced diabetic albino rats, Pak J Nutr. 8 (2009) 551-557.

[5] M.T. Bello, S.S. Nupo, Y.K. Bello, A.O. Shobo, Effect of aqueous Mormodaica charantia on alloxan-induce diabetic rat, J. Nanomed. Nanotechol. 3(9) (2012) 108.

[6] World Health Organisation, Global report on diabetes, 2016. Retrieved May 11, 2016.

[7] The cost of diabetes: American Diabetes Association. www.diabetes.org. Retrieved May 11, 2016.

[8] International Diabetes Federation. Diabetes Atlas, Seventh Edition. 2015. www.diabetesatlas.org. Retrieved May 11, 2016.

[9] K. Takeshi, N. Shoichi, K. Yasunori, I. Yasushi, Report of the committee on the classification and diagnostic criteria of diabetes mellitus, Diabetes Res Clin. Pract. 55 (2002) 65-85.

[10] R.F. Dods, Diabetes mellitus, in: L.A. Kaplan, A.J. Pesce, S.C. Kazmierczak ( $4^{\text {th }}$ ed), Clinical Chemistry: Theory and analysis of correlation, Mostly Inc. eds St. Lowis USA, 2003, pp. 580.

[11] A.A. De-Fronzo, R.C. Bonadonna, E. Ferrannini, Pathogenesis of NIDDM. International Text Book of Diabetes Mellitus, $2^{\text {nd }}$ ed, Chichester, John Wiley, England, 1997, pp. 635-712.

[12] J.P. Liu, M. Zhang, W.Y. Wang, S. Grimsgaard. Chinese herbal medicine for type II diabetes mellitus, Cochrane Database Syst Rev. 3 (2004) 3642.

[13] M.Y. Donath, J.A. Ehses. Type I and type II diabetes: NOD the diabetes we thought it was, Proc. Natl. Acad. Sci. 103 (2006) 12217-12218.

[14] F.J.A. Aguilera et al., A study of the anti hyperglycemic effect of plants used as antidiabetic, J. Ethnopharmacol. 61 (1998) 101-110.

[15] M.T. Pepato et al., Fruit of the Jamboree tree (Eugenia jambolana) and experimental diabetes, J. Ethnopharmacol. 96(4) (2005) 3-48.

[16] S.B. Sharma, A. Nasir, K.M. Prabhu, P.S. Murthy, Anti hyperglycemic effect of the plant pulp of Eugenia jambolana in experimental diabetes mellitus, J. Ethnopharmacol. 104 (2006) 367-373.

[17] M. Tanaka et al., Identification of five photosterols from aloe vera gell as antidiabetic compounds, Biol. pharamaceut Bull. 29 (2006) 1418-1422.

[18] O. Firuzi et al., Evaluation of the antioxidant activity of flavonoids by "ferric reducing antioxidant power" assay and cyclic voltammetry, Biochimica et Biophysica Acta (BBA)General Subjects. 172(1) (2005) 174-184.

[19] Alloxan-wikipedia, the free encyclopedia.http://m.wikipedia.org/wiki/alloxan.

[20] B. Gerhard, E. Wertheimer, Alloxan Studies: The action of alloxan homologues and related compounds, J. Biol Chem. 168 (1947) 241-256.

[21] J.S. Dunn, H.L. Sheehan, N.G.B. Mcletchie, Necrosis of Islets of Langerhan produced experimentally, Lancet. 241(6242) (1943) 484-487.

[22] D.L. Eizirik et al., Major species differences between humans and rodents in the susceptibility of pancreatic $\beta$-cell injury, Proc. Natl. Acad. Sci. United States of America. 91(20) (1994) 9253-9256.

[23] B. Tyrberg, A. Anderson, L.A. Borg, Species differences in susceptibility of transplanted and cultured pancreatic Islets to the $\beta$-Cell toxin alloxan, General and Comparative Endocrinology. 122(3) (2001) 238-251.

[24] B.O. Victor, M.A. Funsho, O.S. Ayodele, Effect of aqueous leaves extracts of Ocimum gratissimum (sweet basil) on alloxan induced diabetic rats, Pharmacognosy Magazine. 1(2) (2005) 62-64.

[25] Y. Tanko et al., Effect of hydromethanotic leaves extract of Indigofera pulchra on blood glucose level of normoglycemic and alloxan- induced diabetic Wister rats, International Journal of Applied Research in Natural Products. 1(4) (2008) 13-18.

[26] O.C.M. Herbert et al., Evaluation of the hypoglycemic effect of aqueous extract of Phyllanthus amarus in alloxan-induced diabetic albino rats, Int. J. Pharm. Biomed. Res. 2(3) (2011) 158-160. 
[27] C.O. Okoli et al., Evaluation of anti diabetic potentials of Phyllanthus niruri in alloxan diabetic rats, African Journal of Biotechnology. 9(2) (2009) 248-259.

[28] B.B. Shehu, A. Gidado, L.B. Buratai, Hypoglycemic effect of extract of Hyphaene thebaica fruit pulp in normal and alloxan-induced diabetic rats, Journal of Medical and Applied Bioscience. 6(1) (2014) 6-15.

[29] M.M. Anakpa, I.U. Asuzu, Histopathological changes and anti diabetic activities of Icacina trichantha tuber extract in beta cells of alloxan induced diabetic rats, Asian Pac J Trop Biomed. 3(8) 2013 628-633.

[30] S. Modu, A.E. Adeboye, A. Maisaratu, B.M. Mubi, Studies on the administration of Vernonia amygdalina Del (Bitter leaf) and glucophage on blood glucose level of alloxan-induced diabetic rats, International Journal of Medicinal Plants and Alternative Medicine. 1(1) 2013 013-019.

[31] E.O. Eze, M. Mohammed, K.Y. Musa, Y. Tanko, Evaluation of effect of ethanolic leaf extract of Mucuna pruriens on Blood Glucose level in alloxan-induced diabetic Wister rats, Asian Journal of Medicinal Science. 4(1) (2012) 23-28.

[32] O.D. Omodamiro, M.A. Jimoh, Hypoglycemic effect ethanol leaves extract of Anacardium occidentale and Gomphrena globosa plants on alloxan induced diabetic rats, J. Chem. Pharm. Res. 6(1) (2014) 492-498.

[33] A. Jimoh, Y. Tanko, A. Mohammed, Anti-diabetic effect of methanol leaf extract of Cissus cornifolia on alloxan-induced hyperglycemic in Wister rats, Annals of Biological Research. 4(3) (2013) 46-54.

[34] E.A. Balogun, O.A. Akinloye, A.A. Lasisi, O.E. Adeyi, Biochemical and histological changes associated with treatment of malaria and diabetic mellitus in mice with extracts of Mormodaica charantia, International Journal of the Nigeria society for Experimental Biology. 24(1) (2012) 38-47.

[35] R.A. Aladodo, N.O. Muhammed, G.A. Balogun, Effect of aqueous root extract of Jatropha curcas on hyperghycaemic and heamotological indices in alloxan induced diabetic albino rats, Fountain Journal of Natural and Applied Sciences. 2(1) (2013) 52-58.

[36] R.J. Ojo, A.E. Memudu, C.O. Akintayo, I.S. Akpan, Preventive effect of Allium sativum on alloxan-induced diabetive rats, ARPN Journal of Agricultural and Biological Science. 7(6) (2012) 609-612.

[37] E.E. Asanga, E.P. Ebong, A.O. Eseyin, Hematological parameters of alloxan-induced diabetic rats treated with ethanol extract and fractions of Nauclea latifolia leaves, European Scientific Journal. 9(27) (2013) 203-210.

[38] E.E. Asanga, E. Patrick, A.E. Olorunfemi, Hypoglycemic effect of ethanol extract and fractions of Nauclea latifolium leaves on normal and alloxan-induced diabetic rats, International Journal of Biochemistry and Biotechnology. 2(6) (2013) 457-460.

[39] P.M. Aja et al., Evaluation of anti diabetic and liver enzymes activity of aqueous extract of Moringa oleifera and Bridelia ferruginea leaves in alloxan induced diabetic albino rats, International Journal of Biochemistry Research and Review. 3(3) (2013) 248-258.

[40] Y.A. Oyedepo, S.O. Babarinde, T.A. Ajayeoba, Evaluation of anti-hyperlipidemic effect of aqueous leaves extract of Moringa oleifera in alloxan induced diabetic rats, International Journal of Biochemistry Research and Review. 3(3) (2013) 162-170.

[41] C.O. Edoga, O.O. Njoku, E.N. Amadi, J.J. Okeke, Blood sugar lowering effect of Moringa oleifera in albino rats, International Journal of Science and Technology. 3(1) (2013) 88-90. 